\title{
DIALOG FILOZOFII Z HISTORIĄ: ZAGADKOWY WSTĘP DO HISTORII POWSZECHNEJ TEOFILAKTA SIMOKATTY
}

W zachowanej tradycji rękopiśmiennej tekst Dialogu Filozofii z Historiq występuje przed obszernym spisem treści i tekstem głównym Historii

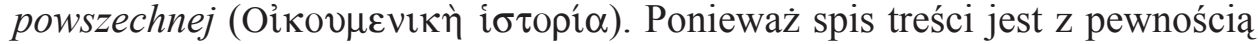
nieautentyczny i został dodany znacznie później (o czym pisaliśmy w innym miejscu ${ }^{1}$ ), zatem można przyjać, iż pierwotnie tekst dialogu poprzedzał bezpośrednio tekst główny. Ten swoisty wstęp odautorski, napisany w dość mętnym stylu, jest bardzo zwięzły: obejmuje zaledwie piętnaście akapitów, na które złożyło się kilkadziesiąt zdań. Nie odwołuje się przy tym do tekstu głównego, lecz stanowi samodzielną treściowo i kompozycyjnie całość. Niniejszy artykuł stawia sobie za cel przedstawienie przesłania, ukrytego za metaforyką wstępu, oraz wskazanie jego hipotetycznych adresatów.

Uczeni, którzy dotychczas analizowali i thumaczyli Historie powszech$n q$, jedynie zdawkowo wspominali o Dialogu we wstępnych partiach swoich opracowań, koncentrując się na podkreślaniu jego autentyczności mimo zaskakującej formy ${ }^{2}$. Niniejszy tekst jest samodzielnym doń komentarzem, proponującym określoną drogę interpretacji. Dotychczas posiadamy jeszcze dwie tego typu prace: dawny, powszechnie cytowany, artykuł Theodora Nissena (1873-1946) ${ }^{3}$ oraz niedawny przekład litewski z komentarzem pióra Tatjany Alekniené ${ }^{4}$, tłumaczki i komentatorki Platona.

* Dr hab. Anna Kotłowska, prof. UAM - profesor nadzwyczajny w Pracowni Historii Bizancjum w Instytucie Historii na Wydziale Historycznym Uniwersytetu im. Adama Mickiewicza w Poznaniu; e-mail: anna.kot@amu.edu.pl.

${ }^{1}$ Por. A. Kotłowska - Ł. Różycki, in collaboration with Andreas Gkoutzioukostas, De Historiarum indice Theophylacto Simocattae falso attributo observationes selectae, „Res Gestae” 5 (2017), w druku.

${ }^{2}$ Theophülaktosz Szimokattész, Világtörténelem, Ford., a bevezetést és a jegyzeteket írta: T. Olajos, Magyar Östörténeti Könyvtár 26, Budapest 2012, 23-24; The History of Theopylact Simocatta, An English Translation with Introduction and Notes by M. and M. Whitby Oxford 1986, 40-45; Theophylaktos Simokates, Geschichte, über. und erl. von P. Schreiner, Bibliothek de Griechischen Literatur 20, Stuttgart 1985, 13-14.

${ }^{3}$ Por. Th. Nissen, Das Prooemium zu Theophylakts Historien und die Sophistik, „Byzantinischneugriechische Jahrbücher" 15 (1939) 3-13.

${ }^{4}$ Por. T. Alekniené, Istorijos teatrai: Filosofijos ir Istorijos pokalbis Teofilakta Simokato 
Rzeczą fundamentalną dla właściwego odczytania Dialogu jest zrozumienie znaczenia personifikacji Filozofii, na co wcześniejsi komentatorzy nie zwracali należytej uwagi. Koncepcja powyższa ma pradawną tradycję, przy czym ujęcia grecko- i łacińskojęzyczne nie różnią się w sposób istotny ${ }^{5}$. Została też ona schrystianizowana, przeistaczając się ostatecznie w ideę Sofii ${ }^{6}$, ale - i to pierwszy istotny wniosek - Teofilakt pozostaje całkowicie na płaszczyźnie klasycznej. Nie jest to oczywiste, gdyż mógł on sięgnąć chociażby do Grzegorza z Nazjanzu dla którego filozofia, umieszczona w jednoznacznie chrześcijańskim kontekście, została wszakże tradycyjnie zdefiniowana jako wiedza $(\dot{\varepsilon} \pi \iota \tau \tau \eta \mu \eta)$ na temat wszelkich rzeczy boskich i ludzkich, której naturą jest prawda $(\alpha \lambda \hat{\eta} \theta \varepsilon ı \alpha)^{7}$. Nurt platoński personifikuje Filozofię, używając

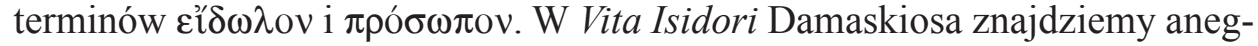
dotę jak to młody Izydor, gdy po raz pierwszy ujrzał Proklosa, wykrzyknął, że

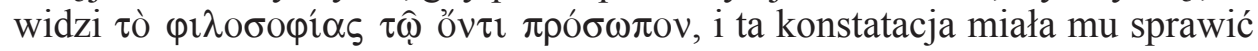

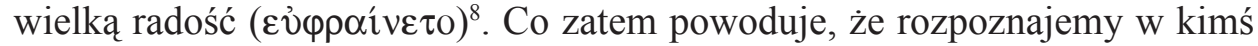
ową personifikację? Są to, mianowicie, nierozłącznie z nią związane, dys-

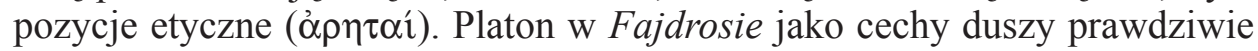
pięknej wymienia $\delta ı \alpha \_$ióv jeszcze rzecz bardzo ważną - Prawdę ( $\alpha \lambda \eta \theta \hat{)})$. 'E $\pi \imath \tau \eta \dot{\mu} \mu \eta$ zawsze pojawia się na końcu tych charakterystyk ${ }^{11}$. Jest zdolnością nabytą dzięki przejściu wcześniejszej formacji etycznej. Kulturze łacińskiej przyswoi te koncepcje Cyce-

„Istorijos ľžangoje”, „Literatūra” 46 (2008) nr 3, 23-40. W tym miejscu chciałabym podziękować Pani Tatjanie Alekniené za udostępnienie tekstu [list z 19.01.2018].

${ }^{5}$ Por. W.E. Helleman, Penelope as Lady Pilosophy, „Phoenix” 49 (1995) 283-302; P. Courcelle, Le personnage de Philosophie dans la littérature latine, „Journal des Savants” (1970) nr 4, 209-252; tenże, Le visage de Philosophie, REA 70 (1968) 110-120.

${ }^{6}$ Literatura na ten temat zapełniłaby niejedną bibliotekę, niemniej warto wspomnieć niedawna monografię Zofii A. Brzozowskiej, Sofia. Upersonifikowana Mąrość Boża. Dzieje wyobrażeń w kręgu kultury bizantyńsko-słowiańskiej, Byzantina Lodziensia 24, Łódź 2015.

${ }^{7}$ Por. Gregorius Nazianzenus, Oratio XXX 20, 15-16, ed. P. Gallay, SCh 250, Paris 1978, 268 (= PG 36, 129A-B). Jest to niemal dosłowne powtórzenie Filona z Aleksandrii (De congressu eruditionis gratia 79, ed. P. Wendland, w: Philo Alexandrinus, Opera quae supersunt, vol. 3, Berolini $1898,88,2)$.

${ }^{8}$ Damascius, Vita Isidori Fragm. 129, ed. C. Zintzen, Hildesheim 1967, 111.

${ }^{9}$ Plato, Phaedrus XXX-XXXI 250B-251A, rec. C.F. Hermann, w: Plato, Dialogi, vol. 2, Lipsiae

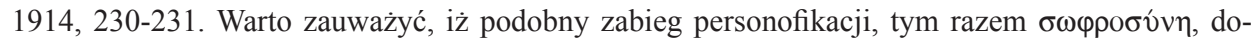
konuje cesarz Julian, widząc jej ucieleśnienie w cesarzowej Euzebii († 360) w: Iulianus Imperator, Ad honorem Eusebiae imperatricis II [III] 14, 45-58, 123a-c, ed. J. Bidez, w: Julien (L'Empereur), Oeuvres complètes, t. 1, $1^{\text {re }}$ partie: Discours de Julien César, Paris 1932, 97. Por. M.P. García Ruiz,

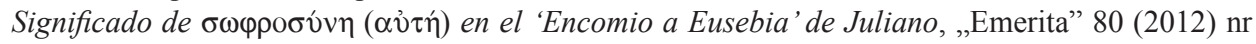
1, 69-87.

${ }^{10}$ Por. Plotinus, Enneades I 6, 4-6, ed. R. Volkmann: Plotinus, Enneades, vol. 1, Lipsiae 1883, $88,30-92,28$.

${ }^{11}$ Por. Plato, Phaedrus XXVIII 247D-E, rec. Hermann, vol. 2, s. 227-228; tenże, Meno XXIIXXV 87C-89A, rec. C.F. Hermann, w: Plato, Dialogi, vol. 3, Lipsiae 1901, 324-325. 


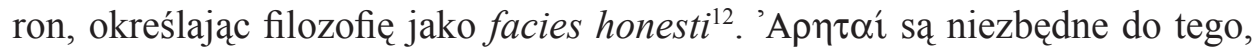
by filozofia - „wcielona wiedza” ( $\theta \varepsilon$ opí $\alpha \sigma \omega \mu \alpha \tau \omega \theta \varepsilon \hat{\imath} \sigma \alpha$, jak pisze Teofilakt w dwunastym akapicie Dialogu) naprawdę mogła się stać „umiłowaniem mądrości”.

Powyższe refleksje wstępne były niezbędne do tego, by móc właściwie odczytać metaforykę, kryjącą się w narracji Dialogu. Inicjatorką rozmowy jest Filozofia, która zwraca się do Historii - nazywając ją przy tym córką

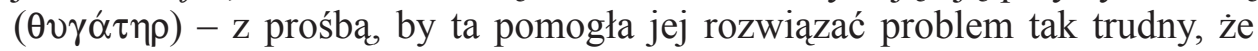
czuje się jak w labiryncie ${ }^{13}$. Przysłowiowość tego wyrażenia jest powszechnie zrozumiała i przywołuje równie mocną scenę z Dantego:

„Nel mezzo del cammin di nostra vita

mi ritrovai per una selva oscura,

ché la diritta via era smarrita"14.

Tu ciemny las, tam labirynt jednoznacznie wskazują na zagubienie w sytuacji moralnie ambiwalentnej, gdy potrzebujemy wiarygodnego przewodnika: Wergiliusza albo Ariadny, Dla Teofilakta Ariadna, która zapewnia „nić zrozu-

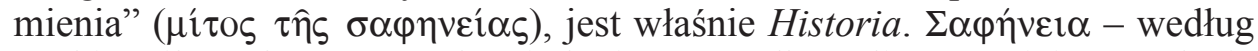
nauki stoików, którzy wszakże jedynie uporządkowali wcześniejszą tradycję

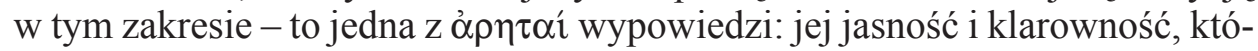
ra odpowiada za zrozumienie przekazu ${ }^{15}$. Definicja powyższa nie uległa później zmianie i dlatego możemy spotkać we wczesnej egzegezie biblijnej takie

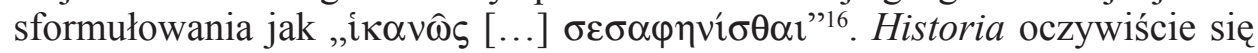
zgadza, mówiąc o pragnieniu wiedzy o wszystkim co piękne słowami Kallimacha ${ }^{17}$ i z szacunkiem nazywając Filozofie „królową wszystkiego" ( $\pi$ óv $\tau \omega \nu$

${ }^{12}$ Cicero, De officiis I 5, 15, rec. C. Atzert, w: Cicero, Scripta quae manserunt omnia, fasc. 48, Lipsiae 1963, 6, 18.

${ }^{13}$ Theophylactus Simocatta, Philosophiae et historiae dialogus 1, ed. C. de Boor - P. Wirth: Theophylactus Simocatta, Historiae, Stutgardiae 1972, 20, 4-7.

${ }^{14}$ Dante Alighieri, La divina commedia, Inferno I 1, 1-3, ed. C.F. Fontana: Dante Alighieri, La divina commedia, Vita e Pensiero, Milano 1950, 39.

${ }^{15}$ Por. Diogenes Laertius, Vitae philosophorum VII 59, ed. by R.D. Hicks: Diogenes Laertius,

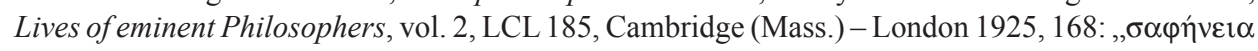

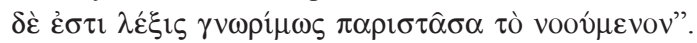

${ }^{16}$ Makarios Magnes, Apokritikos II 7, 13 hrsg. von U. Volp: Makarios Magnes, Apokritikos: Kritische Ausgabe mit deutscher Übersetzung, TU 169, Berlin - Boston 2013, 18.

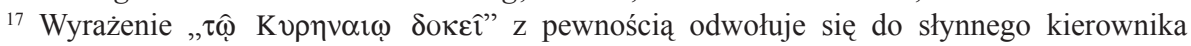
Biblioteki Aleksandryjskiej (tak Pfeiffer, który umieścił to sformułowanie pod numerem 620 swoich Fragmenta - Callimachus, Fragmenta 620, ed. R. Pfeiffer: Callimachus, [Works], vol. 1, Oxonii 1949, 421). Teofilakt używa tego sformułowania jeszcze raz w swych Quaestiones physicae (1, ed. L. Massa Positano, w: Teofilatto Simocata, Questioni naturali, Collana di Studi Greci 23-24, Napoli 1965, 13, 7-8). Powoływanie się na autorytet Kallimacha było popularne w późnym antyku, por. np. Julian w liście do Alypiusa (Iulianus Imperator, Epistulae 10 (30), 403d, coll. I. Bidez F. Cumont: Iulianus Imperator, Epistulae, leges, poemata, fragmenta varia, Paris - London 1922,

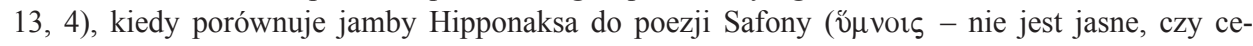


$\left.\beta \alpha \sigma^{\prime} \lambda \lambda^{2} \alpha\right)$. Klio jest przecież jedną z dziewięciu Muz, służek Filozofii, szczególnie odpowiedzialną za - jak to niezwykle trafnie wyraził w swej korespondencji Seneka ${ }^{18}$ - sensus communis, „wymiar wspólnotowy”. Aulus Gellius w Nocach attyckich zachował przydatny w kontekście niniejszych rozważań fragment komedii Afraniusza Krzesło (Sella). W poł. II w. prz. Chr. Afraniusz tworzył togaty, tzn. komedie, których fabuła umieszczona była w realiach rzymskich. Znane są 43 tytuły jego sztuk, jednak żadna nie zachowała się w całości, a na ok. dwieście zidentyfikowanych fragmentów składa się mniej więcej 430 wersów $^{19}$. Z interesującej nas sztuki Krzesło posiadamy dwa fragmenty, których szerszy kontekst jest nie do ustalenia. Niemniej, fakt ten nie rzutuje na bieżącą analizę. Fragment ów brzmi następująco:

„Vsús me genuit, máter peperit Mémoria,

Sophiám vocant me Grái, vos Sapiéntiam"20.

Memoria czyli, „pamięć o przeszłości”, jest zatem nieodzownym elementem wspólnotowego, społecznego wymiaru Mądrości, a jej „,naukową”, by tak rzec, reprezentantką jest Klio - Historia. Podkreślanie roli pamięci nie jest niczym nowym. Już Heraklit nauczał, że „będziemy żyć w prawdzie ( $\alpha \lambda \eta \theta \varepsilon v ́ o \mu \varepsilon v)$, jeśli będziemy mieli świadomość pamięci $(\mu v \eta ́ \mu \eta)$, w przeciwnym razie będziemy błądzić ( $\psi \varepsilon v \delta o ́ ~ \mu \varepsilon \theta \alpha)^{\prime 21}$. W naukach szkoły pitagorejskiej, przekazanych przez Jamblicha, znajdziemy passus o ,zbawczej roli pamięci $(\mu v \eta \mu \eta)$,

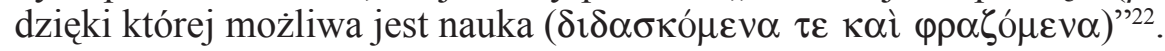

Cóż to zatem jest za problem tak poważny, że nawet Philosophia, vero omnium mater artium $^{23}$, potrzebuje pomocy? Już sam termin grecki:

sarz miał tu na myśli także poezję w metrum jambicznym, czy tylko o „tematyce”, która dominuje w jambach: G. Agosti, Late Antique Iambics and Iambike Idea, w: Iambic Ideas: Essays on a Poetic Tradition from Archaic Greece to the Late Roman Empire, ed. by A. Cavarzere - A. Aloni A. Barchiesi, Lanham 2001, 219-255, spec. 222-230; T. Hawkins, Iambic Poetics in the Roman Empire, Cambridge 2014, 271-273), przytacza na jego temat opinię „poety z Cyrene”, co oznacza bezsprzecznie Kallimacha. Dlatego nie możemy przyjąć alternatywnej hipotezy, wskazującej na Arystypa (tak wszakże T. Alekniené, Istorijos teatrai, s. 25, ze względu na prezentowaną przez nią tezę, iż jest to zawoalowana aluzja do kręgu sokratejskiego). Filozof ten był mało znany i nie uważano go za autorytet w kulturze późnoantycznej.

${ }^{18}$ Por. Seneca, Epistulae ad Lucilium VI 2(54), 7, ed. O. Hense, w: Seneca, w: Seneca, Opera quae supersunt, vol. 3, Lipsiae 1914, 166. 16-24. W akapicie kończącym ten list zamieszczona została także metafora labiryntu, jako zagubienia drogi życiowej, miotania się.

${ }^{19}$ Por. E. Skwara, Historia komedii rzymskiej, Warszawa 2001, 140-143.

${ }^{20}$ Aulus Gellius, Noctes Atticae XIII 8, 3, ed. C. Hosius: Aulus Gellius, Noctes Atticae, vol. 2, Lipsiae 1903, 62, 10-11.

${ }^{21}$ Por. Herakleitos, Fragmenta 12 A 16 (60), hrsg. von H. Diels, w: Die Fragmente der Vorsokratiker. Griechische und Deutsch, vol. 1, 3. Aufl., Berlin 1912, 75, 33-34.

${ }^{22}$ Pythagoreische Schule, 45 D 1 (282), hrsg. von Diels, w: Die Fragmente der Vorsokratiker, vol. 1, s. 361, 25-26.

${ }^{23}$ Cicero, Tusculanae disputationes I 16, 64, rec. M. Pohlenz, w: Cicero, Scripta quae supersunt omnia, fasc. 44, Lipsiae 1918, 249, 15-16. 
$\delta 1 \alpha \pi$ óp $\mu \alpha$, budzi uzasadnione zainteresowanie. Jest bardzo rzadki, spotykany niemal wyłącznie w pismach filozoficznych Perypatu (np. tytuł traktatu

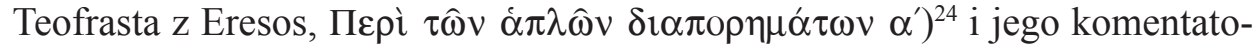
rów (np. Aleksandra $\mathrm{z}$ Afrodyzji ${ }^{25}$, Michała $\mathrm{z} \mathrm{Efezu}^{26}$ ). Nie ulega wątpliwości, że to, iż Teofilakt go użył, było zabiegiem ewidentnie celowym, mającym przykuć uwagę odbiorcy i uczulić na to, że problem jest niezwykle trudny do rozwiązania, a zarazem jest to problem najwyższej wagi. W najdłuższej w całym Dialogu jednolitej wypowiedzi, niejasnej, poprzerywanej mętnymi aluzjami i mitologicznymi metaforami, Filozofia wyjawia wreszcie istote problemu: jak pisać prawdę w czasach politycznego przesilenia? Wyraża to wszystko językiem mitu, mówiąc o „tyranie z Kalydonu”, „Cyklopie”, „pijanym Centaurze", pod którymi to inwektywami kryje się Fokas, stojący w roku 602 na czele wojskowego zamachu stanu ${ }^{27}$. Dobór owych inwektyw nie jest przypadkowy. Pierwsza, ,tyran z Kalydonu”, symbolizuje bezbożność: Artemida zesłała potwornego dzika, gdyż Ojneus, król Kalydonu, lekceważąco zapomniał o złożeniu dlań ofiary 28 . $Z$ bestią tą musieli się później zmagać herosi greccy, przybyli z całej Hellady ${ }^{29}$, a pamięć o tym polowaniu przetrwała tysiąclecia, uwieczniona chociażby na obrazie Rubensa ${ }^{30}$. Druga inwektywa, „Cyklop”, oddaje dzikość i wręcz nieludzki charakter, czego symbolicznym apogeum było ludożerstwo Polifema ${ }^{31}$, przedstawiciela najdzikszego z trzech gatunków Cyklopów. Wreszcie trzecia, ,pijany Centaur”, to brak umiarko-

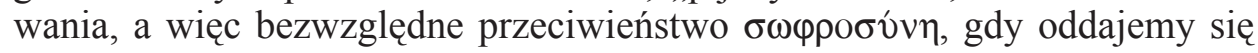
naszym zmysłom bez opamiętania, niczym Centaury, które znane były z tego,

${ }^{24}$ Diogenes Laertius, Vitae philosophorum V 46, ed. by R.D. Hicks: Diogenes Laertius, Lives of eminent Philosophers, vol. 1, LCL 184, Cambridge (Mass.) - London 1909, 494.

${ }^{25}$ Por. Alexander Aphrodisiensis, In Aristotelis Metaphysica commentaria IX 2, 584 (p. 1053 b 9), ed. M. Hayduck: Commentaria in Aristotelem graeca, vol. 1, Berolini 1891, 612, 10. Diaporema

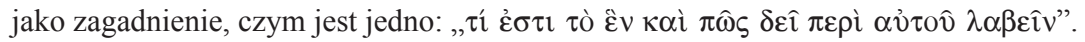

${ }^{26}$ Por. Michael Ephesius, In librum de animalium motione commentarium $150^{v} 20$ (p. 699 a 12), ed. M. Hayduck: Michael Ephesius, In libros de partibus animalium, de animalium motione, de animalium incessu commentaria, Commentaria in Aristotelem graeca, vol. 22/2, Berolini 1904, 108, 8.

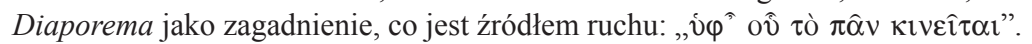

${ }^{27}$ Por. Theophylactus Simocatta, Philosophiae et historiae dialogus 4, ed. de Boor - Wirth, s. $20,15-19$.

${ }^{28}$ Por. Homerus, Ilias IX 533-546, ed. W. Leaf: Homer, The Iliad, vol. 1, Amsterdam $1960^{2}$, 410-411.

${ }^{29}$ Por. Apollodorus, Bibliotheca I 8, 2, ed. by J.G. Frazer, w: Apollodorus, The Library, vol. 1, LCL 121, London - New York 1921, 64 i 66.

${ }^{30}$ Nie ma potrzeby (jak M. and M. Whitby, comm. ad loc.) sugerować tu pomyłkę Teofilakta i pomieszanie z dzikiem z Erymantu, którego schwytanie było jedną z prac Heraklesa, albowiem heros ten (alter ego Herakliusza, por. niżej) był też powiązany z Kalydonem, m.in. przez Dejanirę, por. Apollodorus, Bibliotheca II 7, 5, ed. Frazer, vol. 1, s. 256; Bacchylides, Epinikion V 156-169, post B. Snell ed. H. Maehler, w: Bacchylides, Carmina cum fragmentis, Leipzig 1970, 21.

${ }^{31}$ Por. Homerus, Odyssea IX 287-293, ed. ed. G. Dindorf, editio quarta cur. C. Hentze, pars 1: Odyssea I-XII, Lipsiae 1925, 141. 
że po winie kompletnie nie panowały nad sobą. Dwa z nich, Folos i Chejron, zdobyły sławę właśnie dlatego, że były inne od pozostałych, takich jak np. Nessos, który próbował zgwałcić Dejanirę i przyczynił się do strasznej śmierci Heraklesa ${ }^{32}$. Sposób życia Chejrona w okresie bizantyńskim często był elementem dyskursywnym: tak Grzegorz z Nazjanzu podkreśla, że Bazyli Wielki zdobył światowe wykształcenie, nie żyjąc przy tym na sposób Centaura, „wychowawcy bohaterów” ${ }^{\prime 33}$ ( później nawiąże do tych słów Teodor ze Stoudios w pochwale Platona z Sakkoudion, podkreślając, że Platon żył właśnie tak, jak Chejron, ale się z tego powodu nie wywyższa ${ }^{35}$. Zachowanie Centaurów to wręcz antyteza słynnej maksymy delfickiej $\mu \eta \delta \dot{\varepsilon} v$ ơ $\gamma \alpha v$, o której godny naszego najwyższego szacunku Plutarch z Cheronei pisał, że stanowiła dlań osobiście najważniejszą zasadę postępowania ${ }^{36}$.

Kiedy ludzie pokroju Fokasa przejmują rządy w państwie, normalne funkcjonowanie Filozofii przestaje być możliwe. „Anytos zabija Sokratesa” - tak podsumowuje to Teofilakt, akcentując $w$ ten sposób miarę upadku ${ }^{37}$. Nazywa też Anytosa Trakiem, czyniąc tym samym aluzję do uzurpatora jeszcze bardziej czytelną ${ }^{38}$. Fundamentalną rzeczą, kontynuuje Filozofia, jest teraz zachowanie wiarygodności ( $\pi i \sigma \tau \imath \varsigma)$ w czasach zamętu, gdy zwodzą nas ,fałszywe

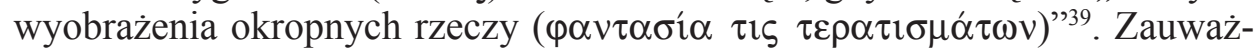

${ }^{32}$ Por. Sophocles, Trachiniae 555-561, ed. R.D. Dave, w: Sophocles, Tragoediae, vol. 2 , Leipzig 1979, 25.

${ }^{33}$ Np. Jazona: Pindarus, Pythia IV 101-116, ed. H. Maehler, w: Pindarus, Carmina cum fragmentis, pars 1: Epinicia, Leipzig 1971, 82; Apollonius Rhodius, Argonautica I 33, rec. R. Merkel, Lipsiae 1913, 2; Achillesa: tamże I 553-558, rec. Merkel, s. 18 (o tym, jak ważny był to mit dla wykształcenia się toposu doskonałego nauczyciela, por. L. Guerrini, Infanzia di Achille e sua educazione presso Chirone, „Studi Miscellanei” 1:1958-1959, 43-53), czy Aristajosa: Apollonius Rhodius, Argonautica II 508-510, rec. Merkel, s. 60. Żona Chejrona miała na imię Chariklo, a matką jego była Filyra, córka Okeanosa.

${ }^{34}$ Gregorius Nazianzenus, Oratios XLIII 12, 9, ed. J. Bernardi, SCh 384, Paris 1992, 140.

${ }^{35}$ Por. Theodorus Studita, Oratio XI: Laudatio S. Platonis Hegumeni 33, PG 99, 837A. Powiązanie między dwoma utworami wykrył Byron MacDougall (Living images and authors of virtue: Theodore of Stoudios on Platon of Sakkoudion and Gregory of Nazianzus on Basil, ByZ 110:2017, nr 3, 691-712, spec. s. 699), który podkreśla, iż mamy tu do czynienia z dyskusją nad najlepszym modelem wychowawczym.

${ }^{36}$ Por. Plutarchus, De E apud Delphos 7, 387 F, rec. W.R. Paton - M. Pohlenz - W. Sieveking,

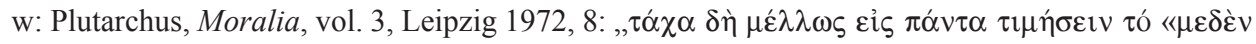

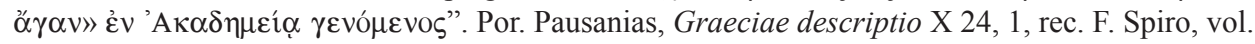

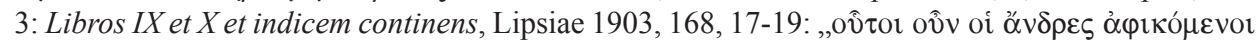

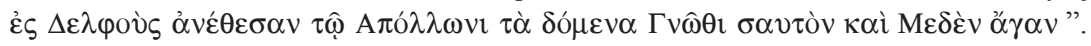

${ }^{37}$ Por. Theophylactus Simocatta, Philosophiae et historiae dialogus 5, ed. de Boor - Wirth, s. 20, 23.

${ }^{38}$ Por. W.E. Kaegi - A. Kazhdan, Phokas, w: Oxford Dictionary of Byzantium, vol. 3, New York - Oxford 1991, 1666; The Prosopography of the Later Roman Empire, vol. 3B, ed. J.R. Martindale, Cambridge 1992, 1030-1032.

${ }^{39}$ Theophylactus Simocatta, Philosophiae et historiae dialogus 3, ed. de Boor - Wirth, s. 20, 14-15. 
my przy tym, że grecka $\varphi \alpha \nu \tau \alpha \sigma i ́ \alpha$ nie ma wiele wspólnego z naszymi mniej lub bardziej niewinnymi „fantazjami”, które są co najwyżej przedmiotem zainteresowania psychologii. Pierwotna $\varphi \alpha \nu \tau \alpha \sigma i \alpha$ to fałsz ${ }^{40}$, przeciwieństwo prawdy, a zatem uderzenie w samo serce helleńskiej etyki; zagrożenie, które może zniszczyć Filozofię.

Zaskakujące jest to, że Historia ostatecznie nie daje odpowiedzi na pytanie Filozofii, problem pozostaje nierozwiązany ${ }^{41}$. Językiem zaś mitu informuje, że po prostu miała szczęście, gdyż ponownie doszło do przewrotu, a władzę przejął Herakliusz (co dobrze oddaje lapidarnie sformułowana aluzja do mitu, w myśl której „Herakles wyprowadził Alkestis”42) i przywrócił „bezwarunko-

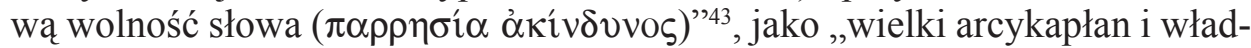
ca całego świata zamieszkałego"44. Pierwsze sformułowanie ma podwójny i łatwy do rozszyfrowania przez ówczesnych sens: z jednej bowiem strony nawiązuje do podobieństwa imion Heraklesa i Herakliusza, z drugiej zaś odwołuje się do niezwykłej popularności Eurypidesa w Bizancjum ${ }^{45}$ i przywodzi na

\footnotetext{
${ }^{40}$ Por. Diogenes Laertius, Vitae philosophorum VII 177, ed. Hicks, vol. 2, s. 284.

${ }^{41}$ Por. Theophylactus Simocatta, Philosophiae et historiae dialogus 9-10, ed. de Boor - Wirth, s. $21,9-17$.

${ }^{42}$ Tamże 9, ed. de Boor-Wirth, s. 21, 11-12. Jest to przewrotna aluzja do słów Feresa, ojca Admeta: Euripides, Alcestis 625-626, rec. A. Nauck, w: Euripides, Tragoediae, vol. 1, Lipsiae 1913, 25.

${ }^{43}$ Theophylactus Simocatta, Philosophiae et historiae dialogus 10, ed. de Boor - Wirth, s. 21, 17.

${ }^{44}$ Tamże 8, ed. de Boor - Wirth, s. 21, 6-7. W przeciwieństwie do wyżej wspomnianych thumaczy Teofilakta (T. Olajos, P. Schreiner, M. and M. Whitby), należy chyba jednak odrzucić przypuszczenie, że jest to odwołanie do patriarchy Sergiusza (610-638; dla M. Whitby'ego, który próbuje tę hipotezę uzasadnić, przesłanką jest patronat patriarchy nad Jerzym z Pizydii (comm. ad loc.). Nigel G. Wilson (Scholars of Byzantium, London 1983, 59-60) natomiast sugerował, że wyrażenie „ $\beta \hat{\eta} \mu \alpha$

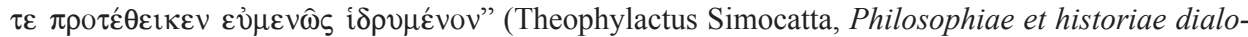
gus 10, ed. de Boor - Wirth, s. 21, 16-17) oznacza stanowisko wykładowcy dla Teofilakta, uzyskane dzięki patriarsze. Powyższa wypowiedź ma jednak wysoki stopień ogólności („But the wording of a sentence about the patriarch suggests that he had created a teaching post, pehaps for the historian himself" - tamże, s. 59) i wydaje się nadużyciem z gatunku petitio principii, albowiem fragment powyższy jest wysoce metaforyczny i taki - jedyny wówczas - wtręt osobisty, kłóciłby się z resztą narracji, która jest na innym poziomie dyskursu, a poza tym nie ma żadnych dowodów na takie postępowanie Sergiusza. Słowa te nie kłócą się w żaden sposób z bizantyńską sakralizacją władzy cesarskiej i stanowią zarazem współczesne zrównoważenie ideowe wcześniej wspomnianego mitu, por. J.D. Frendo, History and Panegyric in the Age of Heraclius: The Literary Background to the Composition of the „Histories” of Theophylact Simocatta, DOP 42 (1988) 144-145; Alekniené, Istorijos teatrai, s. 26-27 (ta ostatnia autorka nie jest do końca zdecydowana na takie rozwiązanie i z wahaniem opowiada się za Sergiuszem). Niewątpliwie obie identyfikacje są teoretycznie możliwe, ale z perspektywy logiki narracji wydaje się, że identyfikacja z Herakliuszem jest bardziej prawdopodobna. Konkludując, musielibyśmy wiedzieć coś więcej o poczynaniach Sergiusza pod rządami Fokasa, bądź o jego relacjach z Teofilaktem, aby zaaprobować tę identyfikację.

${ }^{45}$ Por. B. Baldwin, Euripides in Byzantium, w: The Play of Texts and Fragments. Essays in Honour of Martin Cropp, ed. by J.R.C. Cousland - J.R. Hume, Mnemosyne Supplements 314,

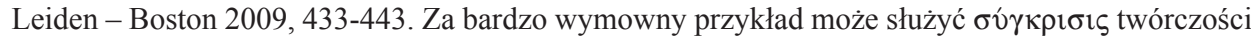
Eurypidesa i Jerzego z Pizydii, którą sporządził Michał Psellos (De Euripide et Georgio Pisida
} 
myśl jego tragedię Alkestis, opartą na dobrze znanym micie. Dramat ten, jak wiadomo, wystawiono po raz pierwszy w roku 438 prz. Chr. i jest to najstarsza z zachowanych sztuk tego tragediopisarza, za którą otrzymał drugą nagrodę ${ }^{46}$. Jednak w gruncie rzeczy podobieństwo to jest dość powierzchowne i można odnieść wrażenie, że cytując Alkestis Teofilakt myślał o niej tak, jak Fajdros w dialogu Platona ${ }^{47}$, a nie jak Eurypides. Drugie wyrażenie, $\pi \alpha \rho \rho \eta \sigma i \alpha$, pochodzące z języka politycznego demokracji ateńskiej ${ }^{48}$, w szerszym aspekcie oznacza wolność wypowiedzi w dramacie (stąd też później Owidiusz oddał ten termin przez libertas: „hoc mihi libertas hoc pia lingua dedit"49, dając tym dowód poszerzenia się jego znaczenia na całokształt wypowiedzi artystycznej,

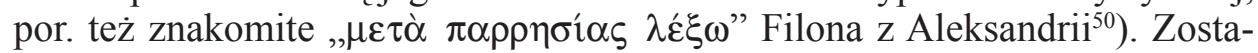
ło ono wzmocnione przez Teofilakta dwiema metaforami mitologicznymi ${ }^{51}$ :

iudicium, ed. A. Colonna, w: Atti dell'VII Congresso Internazionale di Studi Bisantini, Palermo, 3-10 aprile 1951, vol. 1: Filologia, letteratura, linguistica, storia, numismatica, Studi Bizantini e Neoellenici 7, Roma 1953, 16-21; tenże, The Essays on Euripides and George of Pisidia and on Heliodorus and Achilles Tatius, ed. by A.R. Dyck, Foreword by H. Hunger, Byzantina Vindobonensia 16, Wien 1986, 40-50). W przytaczanych tam przez Psellosa egzemplach Alkestis się nie pojawia.

${ }^{46}$ Alkestis, córka Peliasa, dobrowolnie odeszła do Hadesu zamiast męża, Admeta, któremu groziła śmierć za znieważenie Artemidy, por. A. Lesky, Alkestis. Der Mythos und das Drama, Wien - Leipzig 1925 (dzieło klasyczne); tenże, Tragedia grecka, tłum. M. Weiner, Kraków 2006, 330-341 (tam też starsza literatura). W ostatnich dziesięcioleciach komentarze twórczo rozwinęły oraz przeobraziły myśl A. Lesky’ego (7 VII 1896 - 28 II 1981), której główną zasługą było przezwyciężenie wizji Alkestis jako melodramatu, i są zgodne - mimo rozmaitości uzasadnień - że heroiczny czyn tej kobiety, paradoksalnie jedynie podkreśla jej przedmiotowość. W Bizancjum sztuka ta była jeszcze bardziej popularna niż obecnie, np. w XII w. Nikefor Basilakes w Progymnasmata

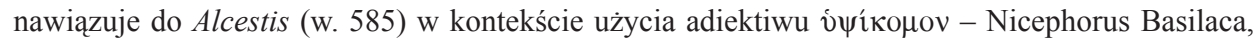
Progymnasmata 55, 72, ed. A. Pignani: Niceforo Basilace, Progimmasmi e monodie, Byzantina et Neo-Hellenica Neapolitana 10, Napoli 1983, 227. Z kolei Konstantyn Stilbes w 55-wersowym poemacie na śmierć przedwcześnie zmarłego ucznia (prawdopodobnie Stefana Heksapterygosa, zm.

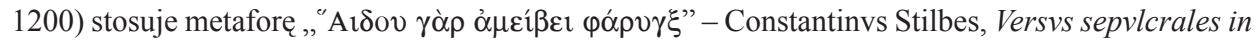
discipvlvm 12, rec. J. Diethart - W. Hörandner: Constantinvs Stilbes, Poemata, Monachii - Lipsiae

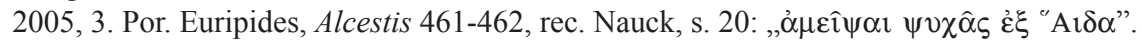

${ }^{47}$ Por. Plato, Symposium VII 179D, rec. C.F. Hermann, w: Plato, Dialogi, vol. 2, Lipsiae 1914,

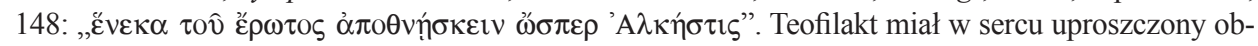
raz z platońskiej Uczty: Alkestis była dla niego idealnym przykładem samopoświęcenia z miłości. Następnie zaś wprowadził Heraklesa ze sztuki, którą doskonale znał, a w dodatku syn Alkmeny przydał mu się do roli wybawiciela doskonałej kobiety-zbawiciela, czyli cierpiącej ojczyzny. Postać w oryginale trzeciorzędna (Herakles) stała się dla Teofilakta pierwszorzędną. Powyższe pomieszanie obrazów pokazuje, jak Bizantyńczycy korzystali z tradycji, traktując ją jako użyteczny słownik metafor, ale niekiedy nie rozumieli, że poszczególne narracje mogą mieć odmienny sens w różnych źródłach.

${ }^{48}$ Por. tenże, Respublica VIII 11, 557B, rec. C.F. Hermann, w: Plato, Dialogi, vol. 4, Lipsiae

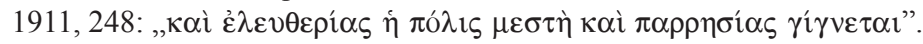

${ }^{49}$ Ovidius, Epistula Sapphus [XV: Sappho Phaoni] XV 68, ed. R. Ehwald, w: Ovidius, Epistulae, vol. 1, Lipsiae 1916, 175.

${ }^{50}$ Philo Alexandrinus, De sacrificiis Abelis et Caini 35, ed. L. Cohn, w: Philo Alexandrinus, Opera quae supersunt, vol. 1, Berolini 1896, 216, 14.

${ }^{51}$ Por. Theophylactus Simocatta, Philosophiae et historiae dialogus 14, ed. de Boor - Wirth, s. $22,8$. 
Historia - w tym nowym okresie wolności - będzie już mówić swobodnie,

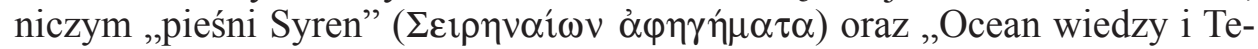

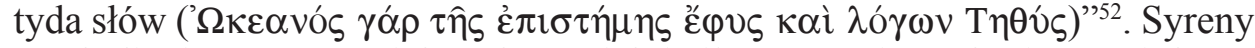
symbolizują zarówno piękno formy jak i siłę zawartej w tekście treści, która jawi się wręcz jako nieodparta moc słowa ${ }^{53}$. Za tą mocą i pięknem podąża bezmiar wiedzy, symbolizowany przez przestwór wód świata, i dopiero razem tworzą one przekaz, którego siła perswazji przekona każdego, a wyrazem tego

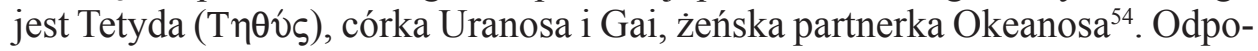
wiedź powyższa, a zarazem cały dialog, zostaje zamknięta - trzeba przyznać dość zaskakującym - wersem Odysei, odnoszącym się do wyspy czarodziejki Kirke, Ajai ${ }^{55}$. Wydaje się, że zakończenie to należy rozpatrywać na dwóch płaszczyznach. Pierwsza to zakamuflowane ostrzeżenie, w myśl którego nie wolno poddać się wpływow fałszu i propagandy, lecz należy wydostać się z owej krainy ułudy i czarów, jaką była wyspa Ajaja, gdzie nic - poza samą Kirke - nie było prawdziwe. Druga natomiast to zamknięcie mitycznego crescendo: dialog zaczyna się metaforą labiryntu, kluczowe exempla degeneracji moralnej należą do najstarszej, przedtrojańskiej warstwy fabularnej, a odpowiedź kończąca dialog, podana jest już słowami największego autorytetu, słowami Poety, które chronologicznie należą do warstwy potrojańskiej. W tej przemyślanej kompozycji nie ma nic przypadkowego.

Mimo tego, że przywrócono wolność Filozofii, wcześniej „ostracyzmowanej z Królewskiego Portyku" ${ }^{56}$, że znowu można - jak w dawnych Atenach ${ }^{57}$

${ }^{52}$ Tamże 15, ed. de Boor - Wirth, s. 22, 10-11.

${ }^{53}$ Por. A. Kotłowska, Zwierzęta w kulturze literackiej Bizantyńczyków, Poznań 2013, 198-209.

${ }^{54}$ Homerus, Ilias XIV 201, ed. Leaf, vol. 2, s. 80; XIV 302, ed. Leaf, vol. 2, s. 88.

${ }^{55}$ Por. Homerus, Odyssea X 195, ed. Dindorf, pars 1, s. 156. Każdy, kto chciałby bliżej zrozumieć istotę wyspy, powinien, zanim zacznie studiować obszerne tomy komentarzy do eposu, zapoznać się z krótkim, lecz niezwykle erudycyjnym i konkretnym tekstem Eduarda Schwyzera (15 II 1874 - 3 V 1943) - Die Insel der Morgenröte, w: tenże, Kleine Schriften, hrsg. von R. Schmitt, Innsbrucker Beiträge zur Sprachwissenschaften 45, Innsbruck 1983, 498-499).

${ }^{56}$ Theophylactus Simocatta, Philosophiae et historiae dialogus 5, ed. de Boor - Wirth, s. 20, 21. Bardzo znacząca aluzja, odnosząca się zarówno do Portyku w Atenach, jak i w Konstantynopolu, znajduje się w: Agathias Myrinaeus, Historiae III 4, rec. R. Keydell, CFHB 2 (Series Berolinensis), Berolini 1967, 84, 12-20. Por. Alekniené, Istorijos teatrai, s. 26.

${ }^{57}$ Por. odniesienie do cykad (Theophylactus Simocatta, Philosophiae et historiae dialogus 10, ed. de Boor - Wirth, s. 21, 14), które wprost nawiązuje do: Thucydides, Historiae I 6, 3, ed. O. Luschnat: Thucydides, Historiae, vol. 1: Libri I-II, Lipsiae 1954, 15, 26-29. Nie należy lekceważyć tej wzmianki, jak to uczynił A.J. Toynbee (14 IV 1889 - 22X 1975) - Greek Historical Thought: From Homer to the Age of Heraclius, introduction and translation by A.J. Toynbee, with two new pieces newly translated by G. Murray, Mentor Book 431, New York 1964, 95), ale też nie ma potrzeby, jak Joseph D. Frendo (History and Panegyric in the Age of Heraclius, s. 150), widzieć w niej aluzję do hojności Herakliusza, która miałaby jakoby umożliwić napisanie Historii. Raczej, wraz z innymi odniesieniami do dawnych Aten, cykady mają symbolizować wolność twórczą w najlepiej do tego przystosowanym społeczeństwie, por. symbolikę cykady: Kotłowska, Zwierzęta w kulturze literackiej Bizantyńczyków, s. 84-86. 
- usiąść pod platanem i rozmawiać, to konkluzja nie jest, niestety, optymistyczna $^{58}$. Ozdrowieńczy ratunek nie przychodzi bowiem z wewnęrznej siły Historii, lecz z niezależnego ośrodka zewnętrznego: nowego kierownictwa państwa. Podsumowując, Dialog Filozofii z Historia to z lekka tylko zawoalowana apologia własnego zachowania sprzed kilkunastoma laty, a także próba ucieczki od jednoznacznych pytań o fakty, o własną biografię, od zakwalifikowania, dość mimo wszystko poniżającego, jako „pisarz dworski” nowej władzy, poprzez obiektywizację czasu i charakteru bieżącej publikacji ${ }^{59}$. A wszystko to wyrażone językiem tradycyjnej paidei, co miało ową obiektywizację wzmocnić, nadając przesłaniu pozory uniwersalizmu poprzez pozbawienie ich konkretyzacji współczesności.

\section{DIALOGUE BETWEEN HISTORY AND PHILOSOPHY: A MYSTERIOUS INTRODUCTION TO THEOPHYLACTUS SIMOCATTES' HISTORY}

\section{(Summary)}

The paper seeks to propose an interpretation of Dialogue between History and Philosophy - prefatory to Simocattes' History. In the author's opinion, this brief text deprived of literary value, provides for Theophylactus' peculiar attempt to justify his actions and behavior during the usurpation of Phokas (602-610). Vague mythological metaphors were meant to divert attention from certain biographical facts and to redirect the discussion to the sphere of universal reflections on the rules of power, thereby releasing Theophylactus from potential liability. Therefore, the Dialogue should be understood as a text of an apologetic nature, written from authors' personal perspective. Such interpretation differs from the

${ }^{58}$ Por. Theophylactus Simocatta, Philosophiae et historiae dialogus 13, ed. de Boor - Wirth, s. 22, 3. Por. Plato, Phaedrus III-IV, 229A-230B, rec. Hermann, vol. 2, s. 204-206; Cicero, De oratore I 7-8, 28-29, ed. K. Kumaniecki, w: Cicero, Scripta quae supersunt omnia, fasc. 3, Leipzig 1969, 12, 6-19. O kontynuacji symboliki platanu w literaturze łacińskiej, por. M. Billerbeck, The Tree of Atedius Melior (Statius, Silvae II, 3), w: Studies in Latin Literature and Roman History IV, ed. C. Deroux, Collection Latomus 196, Bruxelles 1986, 528-536.

59 Jest to odmienna perspektywa od tej, reprezentowanej przez Theodora Nissena (Das Prooemium zu Theophylakts Historien und die Sophistik, s. 12), który, w całym swym tekście podkreślając i zbierając skrzętnie retoryczną stylistykę, uznawał, że dialog jest skierowany bezpośrednio do cesarza Herakliusza. Tę myśl zradykalizował J.D. Frendo (History and Panegyric in the Age of Heraclius, s. 149), sugerując, jakoby utwór powstał na potrzeby „,new regime's official political propaganda". Bardziej wyważony był w swym poglądzie Herbert Hunger (9 XII 1914 - 9 VII 2000) (Die hochsprachliche profane Literatur der Byzantiner, Bd. 1: Philosophie, Rhetorik, Epistolographie, Geschichtsschreibung, Geographie, München 1978, 314-315), który nie negując bynajmniej centralnej postaci Heraklusza („Reverenz vor seinem kaiserlichen Herrn und Auftraggeber (?) Herakleios indirekt und zugleich 'gelehrt' zum Ausdruck zu bringen”), przyznaje jednak, że przesłanki powstania dialogu były osobiste. 
few previous ones which, although scarce, have excessively highlighted rhetorical aspects of the text, suggesting even that it has been written at a request of the new government.

Key words: Theophylactus Simocattes, prooemium, personification of Philosophy, Phokas (Roman emperor, 602-610), Heraclius (Roman emperor, 610-641).

Slowa kluczowe: Teofilakt Simokatta, prooemium, personifikacja Filozofii, Fokas (cesarz rzymski, 602-610), Herakliusz (cesarz rzymski, 610-641).

\section{BIBLIOGRAFIA}

\section{Źródła}

Agathias Myrinaeus, Historiae, rec. R. Keydell, CFHB 2 (Series Berolinensis), Berlin 1967. AleXANDer Aphrodisiensis, In Aristotelis Metaphysica commentaria, ed. M. Hayduck, Commentaria in Aristotelem graeca, vol. 1, Berolini 1891.

Apollodorus, Bibliotheca, ed. with an English translation by J.G. Frazer: Apollodorus,

The Library, vol. 1, LCL 121, London - New York 1921.

Apollonius Rhodius, Argonautica (ad cod. ms. Laurentianum), rec. R. Merkel, Lipsiae 1913.

Aulus Gellius, Noctes Atticae, post M. Hertz ed. C. Hosius, vol. 1-2, Lipsiae 1903.

BACCHYLIDES, Carmina cum fragmentis, post B. Snell ed. H. Maehler, Leipzig 1970.

Callimachus, [Works], vol. 1: Fragmenta, ed. by R. Pfeiffer, Oxonii 1949.

Cicero, De officiis, rec. C. Atzert, w: Cicero, Scripta quae manserunt omnia, fasc. 48: De officiis. De virtutibus, Lipsiae 1963, 1-123.

Cicero, De oratore, ed. K. Kumaniecki, w: Cicero, Scripta quae supersunt omnia, fasc. 3, Leipzig 1969.

Cicero, Tusculanae disputationes, rec. M. Pohlenz, w: Cicero, Scripta quae supersunt omnia, fasc. 44, Lipsiae 1918.

Constantinvs Stilbes, Poemata, rec. J. Diethart - W. Hörandner, Monachii-Lipsiae 2005.

Damascius, Vita Isidori, ed. C. Zintzen, Hildesheim 1967.

Dante Alighieri, La divina commedia, a cura di C.F. Fontana, Vita e Pensiero, Milano 1950.

Diogenes Laertius, Vitae philosophorum, ed. with Englisch translation by R.D. Hicks: Diogenes Laertius, Lives of eminent Philosophers, vol. 1-2, LCL 184-185, Cambridge (Mass.) - London 1925.

EuRIPIDES, Alcestis, , rec. A. Nauck, w: Euriptdes, Tragoediae, vol. 1, Lipsiae 1913, 1-42.

Greek Historical Thought: From Homer to the Age of Heraclius, introduction and translation by A.J. Toynbee, with two new pieces newly translated by G. Murray, Mentor Book 431, New York 1964.

Gregorius Nazianzenus, Orationes, 27-31, introduction, éd. critique, trad. et notes par P. Gallay, avec la collaboration de M. Jourjon, SCh 250, Paris 1978; 42-43, introduction, éd. critique, trad. et notes par J. Bernardi, SCh 384, Paris 1992.

Herakleitos, Fragmenta (12), hrsg. von H. Diels, w: Die Fragmente der Vorsokratiker. Griechische und Deutsch, vol. 1, 3. Aufl., Berlin 1912, 67-113.

Homerus, Ilias, ed. W. Leaf: Homer, The Iliad, vol. 1-2, , Amsterdam $1960^{2}$.

Homerus, Odyssea, pars 1: Odyssea I-XII, ed. G. Dindorf, editio quarta cur. C. Hentze, Lipsiae 1925. 
Iulianus Imperator, Epistulae, leges, poemata, fragmenta varia, coll. I. Bidez - F. Cumont, Paris - London 1922.

Iulianus Imperator, Opera omnia, texte établi et traduit par J. Bidez : Julien (L'Empereur), Oeuvres complètes, t. 1, $1^{\text {re }}$ partie: Discours de Julien César, Paris 1932.

Makarios Magnes, Apokritikos, hrsg. von U. Volp: Apokritikos: Kritische Ausgabe mit deutscher Übersetzung, TU 169, Berlin - Boston 2013.

Michael Ephesius, In libros de partibus animalium, de animalium motione, de animalium incessu commentaria, ed. M. Hayduck, Commentaria in Aristotelem graeca, vol. 22/2, Berolini 1904.

Michael Psellus, De Euripide et Georgio Pisida iudicium, ed. A. Colonna, w: Atti dell' VII Congresso Internazionale di Studi Bisantini, Palermo, 3-10 aprile 1951, vol. 1: Filologia, letteratura, linguistica, storia, numismatica, Studi Bizantini e Neoellenici 7, Roma 1953, 16-21; The Essays on Euripides and George of Pisidia and on Heliodorus and Achilles Tatius, ed. By A.R. Dyck, Foreword by H. Hunger, Byzantina Vindobonensia 16, Wien 1986.

Nicephorus Basilaca, Progymnasmata, testo critico, introduzione, traduzione a cura di A. Pignani: Niceforo Basilace, Progimnasmi e monodie, Byzantina et Neo-Hellenica Neapolitana 10, Napoli 1983.

Ovidius, Epistula Sapphus [XV: Sappho Phaoni], ed. R. Ehwald, w: Ovidius, Epistulae, vol. 1, Lipsiae 1916, 173-179.

Pausanias, Graeciae descriptio, rec. F. Spiro, vol. 3: Libros IX et X et indicem continens, Lipsiae 1903.

Philo Alexandrinus, De congressu eruditionis gratia, ed. P. Wendland, w: Philo Alexandrinus, Opera quae supersunt, vol. 3, Berolini 1898, 72-109.

Philo Alexandrinus, De sacrificiis Abelis et Caini, ed. L. Cohn, w: Philo Alexandrinus, Opera quae supersunt, vol. 1, Berolini 1896, 202-257.

Pindarus, Carmina cum fragmentis, post B. Snell ed. H. Maehler, w: Pindarus, Carmina cum fragmentis, pars 1: Epinicia, Leipzig 1971.

Plato, Meno, rec. C.F. Hermann, w: Plato, Dialogi, vol. 3, Lipsiae 1901, 316-362.

Plato, Phaedrus, rec. C.F. Hermann, w: Plato, Dialogi, vol. 2, Lipsiae 1914, 202-270.

Plato, Respublica, rec. C.F. Hermann, w: Plato, Dialogi, vol. 4, Lipsiae 1911, 1-318.

Plato, Symposium, rec. C.F. Hermann, w: Plato, Dialogi, vol. 2, Lipsiae 1914, 139-201.

Plotinus, Enneades, ed. R. Volkmann, vol. 1, Lipsiae 1883.

Plutarchus, De E apud Delphos, rec. W.R. Paton - M. Pohlenz - W. Sieveking, w: Plutarchus, Moralia, vol. 3, Leipzig 1972, 1-24.

Pythagoreische Schule (45), hrsg. von H. Diels, w: Die Fragmente der Vorsokratiker. Griechische und Deutsch, vol. 1, 3. Aufl., Berlin 1912, 344-374.

SenecA, Epistulae ad Lucilium, ed. O. Hense, w: Seneca, Opera quae supersunt, vol. 3: Ad Lucilium epistularum moralium quae supersunt, Lipsiae 1914.

Sophocles, Trachiniae, ed. R.D. Dave, w: Sophocles, Tragoediae, vol. 2, Leipzig 1979, $1-54$.

Teofilatto Simocata, Questioni naturali, a cura di L. Massa Positano, Collana di Studi Greci 23-24, Napoli 1965.

Theodorus Studita, Oratio XI: Laudatio S. Platonis Hegumeni, PG 99, 804A - 849A.

Theophylactus Simocatta, Historiae, ed. C. de Boor, editionem correctiorem curavit explicationibusque recentioribus adornavit P. Wirth, Stutgardiae 1972; ed. An English Translation with Introduction and Notes by M. and M. Whitby: [Theophylactus Simocatta] The „History” of Theopylact Simocatta, Oxford 1986; über. und erl. von P. Schreiner: Theophylaktos Simokates, Geschichte, Bibliothek de Griechischen Literatur 20, Stutt- 
gart 1985; Ford., a bevezetést és a jegyzeteket írta: T. Olajos: Theophülaktosz Szimokattész, Világtörténelem, Magyar Östörténeti Könyvtár 26, Budapest 2012.

ThuCYDIDEs, Historiae, ed. O. Luschnat, vol. 1: Libri I-II, Lipsiae 1954.

\section{Opracowania}

Agosti G., Late Antique Iambics and Iambike Idea, w: Iambic Ideas: Essays on a Poetic Tradition from Archaic Greece to the Late Roman Empire, ed. by A. Cavarzere A. Aloni - A. Barchiesi, Lanham 2001, 219-255.

Alekniené T., Istorijos teatrai: Filosofijos ir Istorijos pokalbis Teofilakta Simokato „Istorijos Lzžangoje”, „Literatūra” 46 (2008) nr 3, 23-40.

Baldwin B., Euripides in Byzantium, w: The Play of Texts and Fragments. Essays in Honour of Martin Cropp, ed. by J.R.C. Cousland - J.R. Hume, Mnemosyne Supplements 314, Leiden - Boston 2009, 433-443.

Billerbeck M., The Tree of Atedius Melior (Statius, Silvae II, 3), w: Studies in Latin Literature and Roman History IV, ed. C. Deroux, Collection Latomus 196, Bruxelles 1986, 528-536.

Brzozowska Z.A., Sofia. Upersonifikowana Mąrość Boża. Dzieje wyobrażeń w kręu kultury bizantyńsko-stowiańskiej, Byzantina Lodziensia 24, Łódź 2015.

Courcelle P., Le personnage de Philosophie dans la littérature latine, „Journal des Savants" (1970) $\mathrm{nr}$ 4, 209-252.

Courcelle P., Le visage de Philosophie, REA 70 (1968) 110-120.

Frendo J.D., History and Panegyric in the Age of Heraclius: The Literary Background to the Composition of the „Histories” of Theophylact Simocatta, DOP 42 (1988) 143-156.

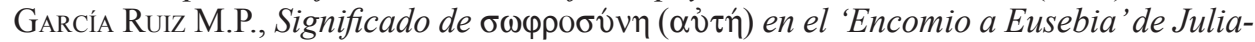
no, „Emerita” 80 (2012) nr 1, 69-87.

Guerrini L., Infanzia di Achille e sua educazione presso Chirone, „Studi Miscellanei” 1 (1958-1959) 43-53.

Hawkins T., Iambic Poetics in the Roman Empire, Cambridge 2014.

Helleman W.E., Penelope as Lady Pilosophy, „Phoenix” 49 (1995) 283-302.

Hunger H., Die hochsprachliche profane Literatur der Byzantiner, Bd. 1: Philosophie, Rhetorik, Epistolographie, Geschichtsschreibung, Geographie, München 1978.

Kaegi W.E. - Kazhdan A., Phokas, w: Oxford Dictionary of Byzantium, vol. 3, New York - Oxford 1991, 1666.

KotŁowska A. - Różycki Ł., in collaboration with A. Gkoutzıoukostas, De Historiarum indice Theophylacto Simocattae falso attributo observationes selectae, „Res Gestae” 5 (2017) [w druku].

KotŁowska A., Zwierzęta w kulturze literackiej Bizantyńczyków, Poznań 2013.

Lesky A., Alkestis. Der Mythos und das Drama, Wien - Leipzig 1925.

LESKY A., Tragedia grecka, tłum. M. Weiner, Kraków 2006.

MacDougall B., Living images and authors of virtue: Theodore of Stoudios on Platon of Sakkoudion and Gregory of Nazianzus on Basil, ByZ 110 (2017) nr 3, 691-712.

Nissen Th., Das Prooemium zu Theophylakts Historien und die Sophistik, „Byzantinischneugriechische Jahrbücher" 15 (1939) 3-13.

Schwyzer E., Die Insel der Morgenröte, w: tenże, Kleine Schriften, hrsg. von R. Schmitt, Innsbrucker Beiträge zur Sprachwissenschaften 45, Innsbruck 1983, 498-499.

SKwara E., Historia komedii rzymskiej, Warszawa 2001.

The Prosopography of the Later Roman Empire, ed. J.R. Martindale, vol. 3B, Cambridge 1992.

WiLson N.G., Scholars of Byzantium, London 1983. 
